\title{
Stimulation of Mitochondrial ATP Synthase Activity - a New Diazoxide-Mediated Mechanism of Cardioprotection
}

\author{
M. JAŠOVÁ ${ }^{1}$, I. KANCIROVÁ ${ }^{1}$, M. MURÁRIKOVÁ ${ }^{\mathbf{1}}$, V. FARKAŠOVÁ ${ }^{\mathbf{1}}$, \\ I. WACZULÍKOVÁ ${ }^{2}$, T. RAVINGEROVÁ ${ }^{1},{ }^{\dagger}$ A. ZIEGELHÖFFER ${ }^{1}$, M. FERKO ${ }^{1}$ \\ ${ }^{1}$ Institute for Heart Research, Centre of Excellence of SAS, NOREG, Slovak Academy of Sciences, \\ Bratislava, Slovak Republic, ${ }^{2}$ Division of Biomedical Physics, Department of Nuclear Physics, \\ Biophysics, Faculty of Mathematics, Physics and Informatics, Comenius University, Bratislava, \\ Slovak Republic
}

Received June 25, 2016

Accepted July 8, 2016

\section{Summary}

Pharmacological preconditioning by diazoxide and a model of experimental streptozotocin-induced acute diabetes mellitus (STZ-DM) provided similar levels of cardioprotection assessed as limiting myocardial infarct size. The aim was to explore the possibility of existence of another in vitro mechanism, which could be contributory to cardioprotection mediated by diazoxide treatment. Mitochondrial membrane fluidity and ATP synthase activity in isolated heart mitochondria were determined under the influence of two factors, STZ-DM condition and treatment with diazoxide. Both factors independently increased the ATP synthase activity $(p<0.05)$, as no interaction effect was observed upon the combination of STZ-DM with diazoxide. On the other hand, the mitochondrial membrane fluidity was significantly increased by STZ-DM only; no significant main effect for diazoxide was found. Based on the results from measurements of enzyme kinetics, we assume a direct interaction of diazoxide with the molecule of ATP synthase stimulated its activity by noncompetitive activation. Our present work revealed, for the first time, that cardioprotection induced by diazoxide may not be caused exclusively by mitochondrial $\mathrm{K}_{\text {ATP }}$ opening, but presumably also by a direct interaction of diazoxide with ATP synthase, although the mechanisms for achieving this activation cannot be fully delineated.

\section{Key words}

Diazoxide - Mitochondrial ATP synthase - Mitochondrial membrane fluidity • Adaptation • Experimental diabetes mellitus

\section{Corresponding author}

M. Ferko, Institute for Heart Research, Centre of Excellence of SAS, NOREG, Slovak Academy of Sciences, Dúbravská cesta 9, 84005 Bratislava, Slovak Republic. E-mail: usrdmife@savba.sk

\section{Introduction}

Several phenomena have been identified that are effective in providing a powerful cardioprotection, such as ischemic preconditioning (IPC) (Murry et al. 1986), ischemic postconditioning (Zhao et al. 2003), remote ischemic conditioning (Przyklenk et al. 1993) and pharmacological preconditioning (Piot et al. 2008, Galano et al. 2011).

Myocardial adaptability to pathological conditions as well as a key role of mitochondria in the process of cardioprotection have been frequently reported. Despite some gaps and uncertainties in the findings by the studies focusing on adaptation mechanisms at the molecular level, the involvement of signaling pathways mediated by opening of mitochondrial permeability transition pores (mPTP) (Kristian et al. 2001), protein kinase C (PKC) activation (Ytrehus and Downey 1994), free oxygen species, or by the mitochondrial ATP-dependent $\mathrm{K}^{+}$channels $\left(\mathrm{K}_{\mathrm{ATP}}\right)$ opening (Liu et al. 1998) is widely accepted. Activation of these essential mechanisms by cardioprotective phenomena leads to a decreased susceptibility of the heart to ischemia/reperfusion injury (I/R) manifesting in better preservation of contractile function and in infarct 
size reduction (Ravingerová et al. 2003, Ferko et al. 2015).

Preconditioning-like effect induced by experimental model of acute streptozotocin-induced diabetes mellitus (STZ-DM) is characterized by better coping of the heart with the increased pathological load (Ziegelhöffer et al. 1996). STZ-DM hearts are characterized by the lack of oxygen consumption due to damage of electron transport chain resulting in a situation similar to ischemia or hypoxia. With regard to the adaptation of the heart to pathological conditions induced by STZ-DM, there were observed many different changes in structural and functional properties of both, cardiomyocytes and heart mitochondria (Pierce and Dhalla 1981, Ferko et al. 2006, 2008, Malfitano et al. 2015). Some of these changes, like an increase in ATP synthase activity and in mitochondrial membrane fluidity, or the protection against $\mathrm{Ca}^{2+}$ overload, were considered to be an adaptation mechanisms of heart mitochondria exposed to an acute stage of STZ-DM (Ferko et al. 2006, 2008, Ziegelhöffer et al. 1996).

Pharmacological preconditioning is one of effective tools for induction of heart adaptation by a chemical agent that influences cardioprotective pathway. Several pharmacological substances for preventing myocardial reperfusion injury were already tested. Inhibiting the formation and opening of MPTP by cyclosporin-A (Piot et al. 2008), free radicals scavenging by melatonin (Galano et al. 2011) or reducing the production of inflammatory mediators (Ebrahimi et al. 2014) have been found to participate in the infarct size reduction and better recovery after I/R injury.

Since the effect of mitochondrial $\mathrm{K}_{\mathrm{ATP}}$ channels openers was assumed to be cardioprotective, one of them, diazoxide, has often been used as a pharmacological tool inducing preconditioning (Garlid et al. 1997, Sanada et al. 2001). Consequences of the induced opening of the mitochondrial $\mathrm{K}_{\mathrm{ATP}}$ channels results in depolarization of intramitochondrial membrane by $\mathrm{K}^{+}$entry which simultaneously brings about reduction in mitochondrial calcium overload (Holmuhamedov et al. 1998).

Diazoxide has also been recognized as an inhibitor of succinate dehydrogenase (Lenzen and Panten 1983), therefore, the defect in the electron transport chain, succinate accumulation likewise the decrease in intracelular $\mathrm{pH}$ can be attributed to the effect of diazoxide. These metabolic changes contribute to the prevention of mPTP opening and simulate conditions equivalent to those of IPC (Garlid et al. 1997).
The question remains whether there is another mechanism - similar to STZ-DM - by which diazoxide could contribute to the endogenous cardioprotection. Investigation of diazoxide effect in terms of changes in structural and functional characteristics of mitochondrial membrane can provide new information about the possible mechanism of diazoxide action in healthy and diabetic myocardium. The aim was therefore to explore the possibility of existence of another in vitro mechanism, which could be contributory to cardioprotection mediated by diazoxide treatment and assessed in terms of an increase in the mitochondrial membrane fluidity and ATP synthase activity.

\section{Material and Methods}

All experiments were performed in accordance with the European Guidelines on Laboratory Animal Care. The use and treatment of animals were also approved by the Ethics Committee of the Institute for Heart Research, SAS where the experiments were carried out.

Male Wistar rats of age 9-11 weeks $(250 \pm 20 \mathrm{~g})$ were kept under conditions of standard light regimen (D:L, 12:12) at $22 \pm 2{ }^{\circ} \mathrm{C}$ in cages (max 5 animals per cage) with access to water and standard pellet food ad libitum.

Experimental diabetes mellitus was induced by a single dose of streptozotocin (STZ) $\left(65 \mathrm{mg} \cdot \mathrm{kg}^{-1}\right.$, i.p.) dissolved in 0.1 mol. $1^{-1}$ citrate buffer, $\mathrm{pH} 4.0$. Progress of disease was monitored during 8 days by measuring of glykosuria using Gluko PHAN strips (Erba-Lachema, Brno, Czech Republic).

Eight days after STZ injection, experimental animals were anesthetized with thiopental (50-60 mg. $\mathrm{kg}^{-1}$, i.p.) together with heparin (500 IU, i.p.).

Metabolic state of animals was determined by estimation of glucose, cholesterol, triacylglycerols and glycohemoglobin (MultiCare, Biochemical system internation, Florence, Italy) in the blood as well as insulin in the serum (RIA kit, Linco Researech USA).

Excised heart was cut into small pieces by scissors in the presence of small volume of ice-cold isolation solution (IS, containing in $\mathrm{mmol}^{-1} \mathrm{l}^{-1} 180 \mathrm{KCl}$, 4 EDTA, $1 \%$ bovine serum albumin, $\mathrm{pH} 7.4$ ). Minced heart tissue was suffused with $20 \mathrm{ml}$ of ice-cold IS with addition of protease $2.5 \mathrm{mg} \cdot \mathrm{g}^{-1}$ of tissue (Sigma P-6141) and subsequently, during 2-3 min, homogenized in teflon/glass homogenizer on the ice. Tissue homogenate 
was processed by differential centrifugation. After $10 \mathrm{~min}$ centrifugation at $1000 \mathrm{~g}$, the obtained supernatant together with the part of mitochondria which were in direct contact with protease were poured out and the pellet containing mitochondria was homogenized in $20 \mathrm{ml}$ of ice-cold IS without protease and centrifugated again at $1000 \mathrm{~g}$ for $10 \mathrm{~min}$. Resulting supernatant was centrifuged at $6200 \mathrm{~g}$ for $10 \mathrm{~min}$ and pellet containing mitochondria was resuspended in an albumin free IS (containing in $\mathrm{mmol}^{-1}{ }^{-1} 180 \mathrm{KCl}$, 4 EDTA). Obtained homogenate was spunned down at $6200 \mathrm{~g}$ for $10 \mathrm{~min}$ and subsequently used for the estimation of protein concentration according to Lowry, as well as for further biophysical and biochemical investigations (Lowry et al. 1951). The procedure of isolation of heart mitochondria was performed at $4{ }^{\circ} \mathrm{C}$ (Ziegelhöffer et al. 2009).

Mitochondrial membrane fluorescence anisotropy was determined by using a lipophilic fluorescence probe 1,6-diphenyl-1,3,5-hexatriene (DPH). The degree of DPH fluorescence anisotropy characterizes the mobility of phospholipid acyl chains in the membrane. The measured fluorescence anisotropy of DPH thus reflects the membrane microviscosity which is a reciprocal of the membrane fluidity. Isolated mitochondria were resuspended in an isotonic buffer containing $180 \mathrm{KCl}\left(\mathrm{mmol} . \mathrm{l}^{-1}\right), 4$ EDTA $\left(\mathrm{mmol} . \mathrm{l}^{-1}\right)$, $\mathrm{pH} 7.4$ and in the presence and absence of 7 diazoxide $\left(\mu \mathrm{mol} .1^{-1}\right)$. Diluted mitochondrial fraction was labeled with a $0.25 \mu \mathrm{mol}^{-1}$ of DPH solution. Samples were incubated at $30 \pm 0.2{ }^{\circ} \mathrm{C}$ in the dark for $20 \mathrm{~min}$ to allow a complete incorporation of the probe into the membrane. Fluorescence anisotropy was measured with luminiscence spectrometer LS 45 (Perkin Elmer, USA) at the excitation wavelength of $360 \mathrm{~nm}$ and the emission wavelength of $425 \mathrm{~nm}$ according to Shinitzky (1984).

The activity of mitochondrial ATP synthase was determined in the presence of $\mathrm{Mg}^{2+}$ cations in the reverse direction of reaction as $\mathrm{Mg}^{2+}$-ATPase, i.e. as a splitting of ATP molecules. Enzyme activity was determined by adding of $50 \mu \mathrm{g}$ mitochondrial fraction $\left(1 \mu \mathrm{g} . \mu \mathrm{l}^{-1}\right)$ into the $950 \mu \mathrm{l}$ of incubation medium containing: $200 \mu \mathrm{l}$ imidazole buffer $\left(250 \mathrm{mmol}^{-1}\right), \quad 100 \mu \mathrm{l} \quad \mathrm{MgCl}_{2}$

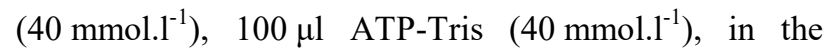
presence and absence of $100 \mu \mathrm{l}$ dinitrophenol (DNP) $\left(0.1 \mathrm{mmol}^{-1} \mathrm{I}^{-1}\right)$ and $200 \mu \mathrm{l}$ diazoxide $\left(0.5-7 \mu \mathrm{mol} . \mathrm{l}^{-1}\right)$ and destilled water added to a total volume of $950 \mu \mathrm{l}$. Addition of DNP disrupts all mitochondrial membranes, thus allowing influx of $\mathrm{Mg}^{2+}$ cations into the mitochondria. In this way it is possible to measure the total activity of mitochondrial $\mathrm{Mg}^{2+}$-ATPase. The reaction started by ATP addition after $10 \mathrm{~min}$ of preincubation of mitochondrial fraction at $37^{\circ} \mathrm{C}$. Termination of reaction was performed by addition of $1 \mathrm{ml}$ ice-cold $12 \%$ trichloroacetic acid, after 20-min incubation of mitochondrial fraction with ATP (Ferko et al. 2006). Finally, the mitochondrial $\mathrm{Mg}^{2+}$-ATPase activity was determined spectrophotometrically at $700 \mathrm{~nm}$ as the amount of inorganic phosphate $\left(\mathrm{P}_{\mathrm{i}}\right)$ liberated by ATP splitting per unit of time ( $\mu$ mol.P $\cdot \mathrm{P}_{\mathrm{i}} \mathrm{g}^{-1} \cdot \mathrm{h}^{-1}$ ) according to Taussky and Shorr (1953).

Determining the type of diazoxide-enzyme interaction is possible by measuring of the dependence of mitochondrial $\mathrm{Mg}^{2+}$-ATPase activity on the increasing concentration of ATP, based on the changes in kinetic parameters: the maximal reaction rate $\left(\mathrm{V}_{\max }\right)$ and Michaelis-Menten constant $\left(\mathrm{K}_{\mathrm{m}}\right)$. Enzyme kinetics of mitochondrial ATP synthase activity was measured in the presence of diazoxide (at a concentration of $7 \mu \mathrm{mol}^{-1} \mathrm{I}^{-1}$ ) and ATP (in the range of concentrations up to $40 \mathrm{mmol}^{-1} \mathrm{l}^{-1}$ ) according to Ziegelhöffer et al. (1996).

Data are presented as a mean \pm standard error of mean (SEM). Differences between groups were evaluated by the method of analysis of variance (ANOVA). For non-normally distributed data we used a nonparametric analysis of variance, Kruskal-Wallis test for an unpaired design or Friedman test for paired comparisons. Fitting enzyme kinetics data was made using nonlinear regression with a model of Michaelis-Menten enzyme kinetics equation. The results were compared with those obtained after standard data transformation yielding linearised dose-response curves. Method of linear regression together with testing of influential points was then used for testing the significance of relations. Statistical analyses were performed using StatsDirect 2.8 .0 (3.0.161) software (Stats Direct Ltd., UK) and GraphPad Prism 6.01 (GraphPad Software, Inc., USA). Two-sided P-values are reported.

\section{Results}

Diabetic state of experimental animals was confirmed by a significant $(\mathrm{p}<0.01)$ increase in the levels of blood glucose, triacylglycerols, cholesterol and the content of glycohemoglobin as well as by decreased levels of blood insulin on the eighth day after the STZ injection (Table 1). 
Table 1. Comparison of the metabolic parameters of control healthy and acute streptozotocin-induced diabetic rats.

\begin{tabular}{lcc}
\hline & $\begin{array}{c}\text { Control } \\
\text { group }\end{array}$ & $\begin{array}{c}\text { Diabetic } \\
\text { group }\end{array}$ \\
\hline Glucose $(\mathrm{mmol} / \mathrm{l})$ & $5.20 \pm 0.14$ & $17.90 \pm 0.84^{*}$ \\
Triacylglycerols $(\mathrm{g} / \mathrm{l})$ & $1.22 \pm 0.11$ & $4.56 \pm 0.34^{*}$ \\
Cholesterol $(\mathrm{g} / \mathrm{l})$ & $1.75 \pm 0.10$ & $2.69 \pm 0.14^{*}$ \\
Glycohemoglobin $(\% \mathrm{Hb})$ & $4.12 \pm 0.10$ & $7.68 \pm 0.92^{*}$ \\
Insulin $(\mathrm{ng} / \mathrm{ml})$ & $1.16 \pm 0.18$ & $0.48 \pm 0.06^{*}$ \\
\hline
\end{tabular}

Results are given as mean \pm SEM; $n=14, * p<0.01$ vs. control healthy group.

Mitochondrial membrane fluidity was measured under a combination of two factors: STZ-DM condition and treatment with diazoxide (DZX). When the effects of factors were considered separately, only the acute stage of STZ-DM yielded statistically significant increase in the membrane fluidity. The second factor, diazoxide, did not have a significant impact on this biophysical parameter. Thus, the observed significant increase in membrane fluidity upon the combination of the two factors can be attributed to the main effect of STZ-DM. Diazoxide did not independently increase membrane fluidity (Fig. 1).

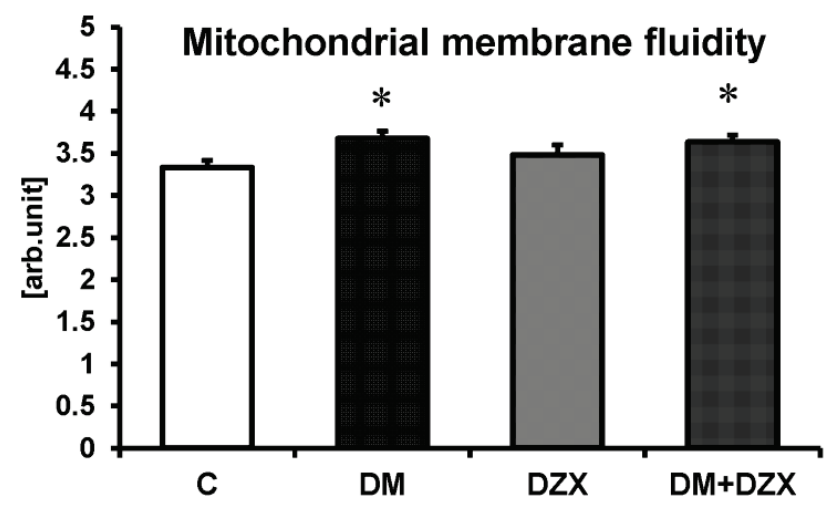

Fig. 1. Modulation of mitochondrial membrane fluidity in control healthy hearts and hearts exposed to acute streptozotocininduced diabetes mellitus and diazoxide. Experimental groups: C, isolated mitochondria from control healthy group; DM, isolated mitochondria from group with acute stage of streptozotocininduced diabetes mellitus; DZX, isolated mitochondria from control healthy hearts exposed to $7 \mu \mathrm{mol}^{-1} \mathrm{l}^{-1}$ diazoxide (in vitro); $D M+D Z X$, isolated mitochondria from hearts with acute streptozotocin-induced diabetes mellitus exposed to $7 \mu \mathrm{mol} . \mathrm{I}^{-1}$ diazoxide (in vitro). Results are given as mean $\pm \mathrm{SEM} ; \mathrm{n}=6$ for each group, $* p<0.05$ vs. control healthy group.

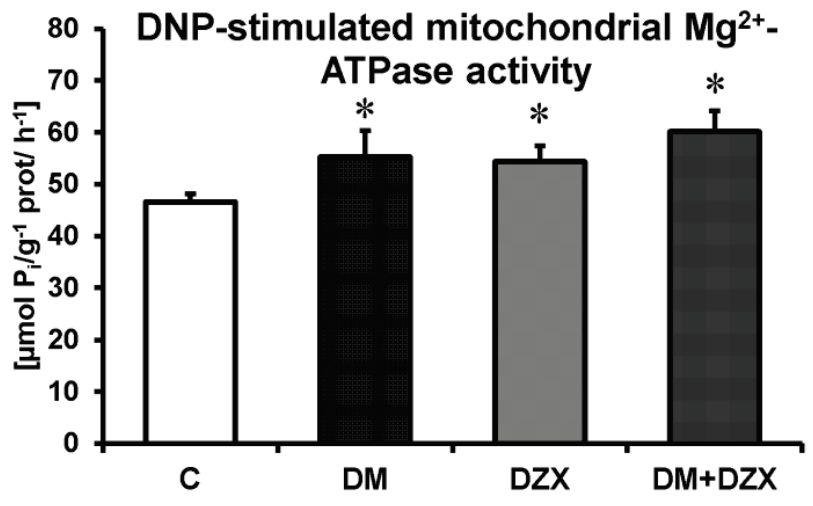

Fig. 2. Activity of DNP-stimulated $\mathrm{Mg}^{2+}$-ATPase in mitochondria isolated from control healthy and acute streptozotocin-induced diabetic rat hearts exposed to diazoxide. Experimental groups: C, isolated mitochondria from control group; DM, isolated mitochondria from group with streptozotocin-induced diabetes mellitus; DZX, isolated mitochondria from control healthy hearts exposed to $7 \mu \mathrm{mol} . \mathrm{I}^{-1}$ diazoxide (in vitro); DM+DZX, isolated mitochondria from hearts with acute streptozotocin-induced diabetes mellitus exposed to $7 \mu \mathrm{mol} . \mathrm{I}^{-1}$ diazoxide (in vitro). Results are given as mean \pm SEM; $n=7$ for each group. $* p<0.05$ vs. control healthy group.

Separate effect of acute STZ-DM was manifested by a significant $(\mathrm{p}<0.05)$ increase in the activity of mitochondrial $\mathrm{Mg}^{2+}$-ATPase by $18.93 \%$. Stimulatory effect of diazoxide on the mitochondrial $\mathrm{Mg}^{2+}$-ATPase activity was proved within the whole monitored range of diazoxide concentrations $\left(0-7 \mu \mathrm{mol} .1^{-1}\right)$ with the statistical significance $(\mathrm{p}<0.05)$ up to $5 \mu \mathrm{mol} . \mathrm{l}^{-1}$ diazoxide including (data not shown). Exposure of mitochondria isolated from healthy and acute STZ-DM hearts to $7 \mu$ mol. $1^{-1}$ diazoxide (under in vitro conditions) induced a significant increase $(\mathrm{p}<0.05)$ in $\mathrm{Mg}^{2+}$-ATPase activity by $16.74 \%$ and $29.09 \%$ in healthy and in acute STZ-DM group, respectively (Fig. 2).

In order to determine the type of diazoxideenzyme interaction, the dependence of ATP synthase activity on the increasing ATP concentration (so called dose-response curves) in the presence of constant diazoxide concentration $\left(7 \mu \mathrm{mol} . \mathrm{l}^{-1}\right)$ were measured in both experimental groups (Fig. 3A,B). Statistically significant increase $(\mathrm{p}<0.05)$ in $\mathrm{V}_{\max }$ in control as well as in diabetic group and no statistically significant change of the $\mathrm{K}_{\mathrm{m}}$ value were observed in the control as well as in the SZT-DM group (Table 2). No significant interaction between the two factors, STZ-DM and diazoxide, was observed, which denotes that the effects of these factors on the $\mathrm{V}_{\max }$ can be considered separately. 

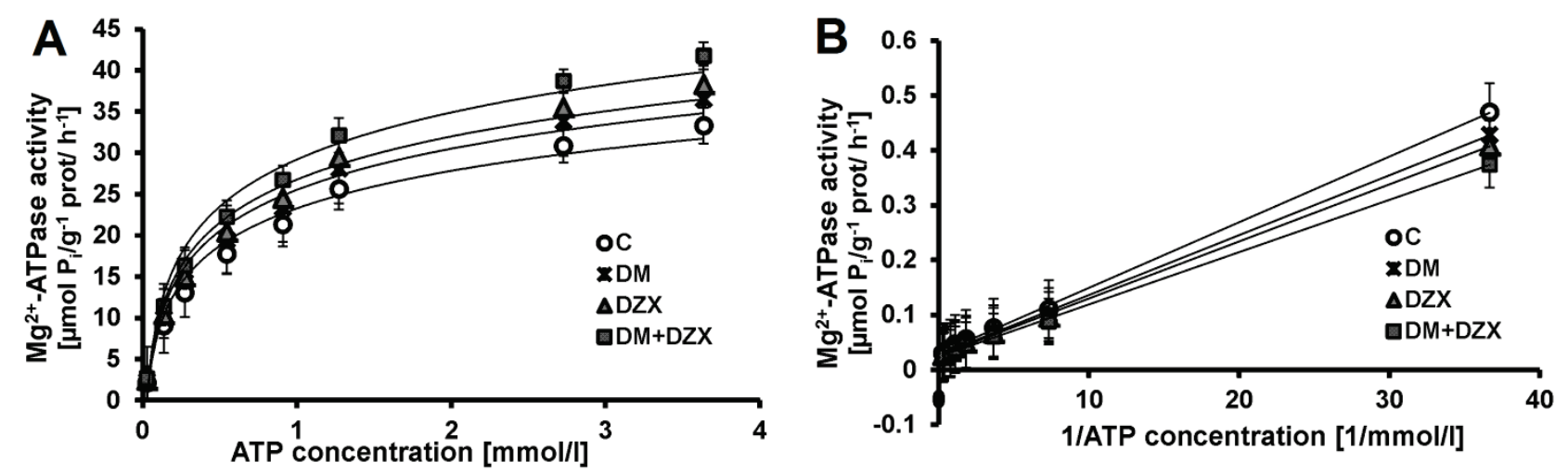

Fig. 3. (A) Activation of mitochondrial $\mathrm{Mg}^{2+}$-ATPase by increasing concentration of ATP in the presence and absence of $7 \mu$ mol..$^{-1}$ diazoxide in control healthy hearts and hearts exposed to acute streptozotocin-induced diabetes mellitus. (B) Lineweaver-Burk plot of mitochondrial $\mathrm{Mg}^{2+}$-ATPase activation. Experimental groups: $\mathrm{C}$, isolated mitochondria from control healthy group; DM, isolated mitochondria from group with streptozotocin-induced diabetes mellitus; DZX, isolated mitochondria from control healthy hearts exposed to $7 \mu \mathrm{mol} . I^{-1}$ diazoxide (in vitro); DM+DZX, isolated mitochondria from hearts with acute streptozotocin-induced diabetes mellitus exposed to $7 \mu \mathrm{mol}^{-1} \mathrm{I}^{-1}$ diazoxide (in vitro). Results are given as mean $\pm \mathrm{SEM} ; \mathrm{n}=7$ for each group.

Table 2. Kinetics parameters of mitochondrial $\mathrm{Mg}^{2+}$-ATPase activation by increasing concentration of ATP in the presence and absence of $7 \mu \mathrm{mol}^{-1} \mathrm{I}^{-1}$ diazoxide in the hearts of control healthy and streptozotocin-induced diabetes mellitus.

\begin{tabular}{llc}
\hline & \multicolumn{1}{c}{$\mathbf{V}_{\mathbf{m a x}}$} & $\mathbf{K}_{\mathbf{m}}$ \\
\hline$C$ & $33.674 \pm 0.861$ & $0.148 \pm 0.004$ \\
$D I A$ & $38.752 \pm 1.080 *$ & $0.147 \pm 0.008$ \\
$D Z X$ & $36.903 \pm 1.134 *$ & $0.148 \pm 0.005$ \\
$D M+D Z X$ & $42.160 \pm 0.982 *$ & $0.148 \pm 0.007$ \\
\hline
\end{tabular}

Results are given as mean \pm SEM. Experimental groups: C, isolated mitochondria from control healthy hearts; $\mathrm{DM}$, isolated mitochondria from hearts of animals with acute streptozotocin-induced diabetes mellitus; DZX, isolated mitochondria from control healthy hearts exposed to $7 \mu \mathrm{mol} . \mathrm{I}^{-1}$ diazoxide (in vitro); DM+DZX, isolated mitochondria from hearts of animals with acute streptozotocin-induced diabetes mellitus exposed to $7 \mu \mathrm{mol} . \mathrm{I}^{-1}$ diazoxide (in vitro). $\mathrm{n}=7$ for each group, $* p<0.05$ vs. control healthy group.

\section{Discussion}

Our attention in this study was focused on the possibilities of pharmacological influencing of already recognized cardioprotective mechanisms induced by acute stage of STZ-DM (Tani and Neely 1988, Ziegelhöffer et al. 1996, Ferko et al. 2006, Malfitano et al. 2015). Diazoxide is considered to be an appropriate agent for modulation of the endogenous protective mechanisms. Whereas diazoxide has proven its protective effect in the physiological parameters, specifically an antiarrhythmic protection in terms of the ventricular premature beats and the total duration of ventricular tachyarrhythmia) (Matejíková et al. 2009), we also focused on the mechanism of diazoxide action.

Acute stage of streptozotocin-induced diabetic animal models has become a very useful platform for understanding cardioprotective mechanisms (Malfitano et al. 2015, Liu et al. 1993). Despite using a wide range of STZ doses (Bhadada and Goyal 2015, Mukundwa et al. 2016) the application of $65 \mathrm{mg} \cdot \mathrm{kg}^{-1} \mathrm{STZ}$ has been shown to be sufficient to cause DM as confirmed by altered metabolic parameters on the eighth day after STZ aplication (Table 1). Moreover, we have already reported that induction of acute stage of STZ-DM by doses of $65 \mathrm{mg} \cdot \mathrm{kg}^{-1} \mathrm{STZ}$ results in a damage of mitochondrial electron transport chain without disconnection of oxidative phosphorylation (Ferko et al. 2006). The decrease in oxygen utilization due to defect in electron transport chain is partially compensated by an increase in mitochondrial membrane fluidity (Ferko et al. 2008, Waczulíková et al. 2007). The degree of membrane fluidity is a very important parameter influencing functional properties of proteins incorporated in the membranes, such as that of activity of mitochondrial ATP synthase (Waczulíková et al. 2002).

In accordance with our recent data, a significant increase in the mitochondrial membrane fluidity was observed in the hearts exposed to STZ-DM (Fig. 1) (Ferko et al. 2008, Waczulíková et al. 2007). An elevated formation of mPTP could be one of the possible explanations of the observed mitochondrial membrane fluidization. Enhanced formation and a short-term MPTP opening observed during the acute STZ-DM resulted in mitochondrial membrane fluidization and facilitation of ATP transport without lethal damage (ZiegelhöfferMihalovičová et al. 1997). 
The increase in membrane fluidity of mitochondrial membranes isolated from the hearts exposed to STZ-DM could presumably result in reducing of local friction, thus facilitating ATP synthase rotation, which was manifested by enhanced ATP synthase activity, measured as DNP-stimulated $\mathrm{Mg}^{2+}$-ATPase activity (Fig. 2). The activity of mitochondrial $\mathrm{Mg}^{2+}$-ATPase is measured in the presence of DNP that makes mitochondrial membranes permeable to $\mathrm{Mg}^{2+}$ ions which enter the mitochondria thus allowing determination of the total enzyme activity. Similarly, the results presented in studies by Ferko et al. $(2006,2008)$ point to the ability of myocardium to adapt on the acute pathological stimulus, STZ-DM, by using the compensative mechanisms originated in mitochondria (increase in mitochondrial membrane fluidity and $\mathrm{Mg}^{2+}$-ATPase activity). The effect of diazoxide did not manifest in an alteration of mitochondrial membrane lipid fluidity. Moreover, combination of STZ-DM with diazoxide did not result in an independent effect of diazoxide. The observed increase can be attributed solely to the effect of STZ-DM (Fig. 1). Based on these results, we can assume that diazoxide did not incorporate into the lipid bilayer, neither affected its composition.

The effect of diazoxide as a cardioprotective agent imitating IPC was observed in the increase of mitochondrial DNP-stimulated $\mathrm{Mg}^{2+}$-ATPase activity (Fig. 2) within the whole diazoxide concentration range 0 to $7 \mu \mathrm{mol}^{-1}$ (data not shown) as was confirmed in studies by Dzeja et al. (2003) and Portenhauser et al. (1971). Interestingly, diazoxide was able to stimulate the increase in enzyme activity independently of STZ-DM condition (Fig. 2).

Based on the results, it can be deemed reasonable to anticipate the involvement of different mechanisms for each of the phenomena leading to cardioprotection. In the model of STZ-DM we observed the supportive effect of mitochondrial membrane fluidization on the increase in mitochondrial DNP-stimulated $\mathrm{Mg}^{2+}$-ATPase activity. On the other hand, the increase in the enzyme activity after diazoxide treatment was not associated by changes in mitochondrial membrane fluidity, which implied existence of a different mechanism by which diazoxide stimulated the $\mathrm{Mg}^{2+}$-ATPase.

Focusing on the elucidation the mechanism of diazoxide action, the kinetics measurements were performed. Dependence of $\mathrm{Mg}^{2+}$-ATPase activity on the increasing concentration of ATP in the presence or absence of diazoxide revealed a significant elevation in $\mathrm{V}_{\max }$ values in all experimental groups compared to the control group (Fig. 3A,B). No statistically significant interaction between the effects of STZ-DM and DZX was proved, and so the effect of DZX can be assumed identical irrespective of the level of the second factor (diabetic and healthy condition). Thus, we can conclude that the factors STZ-DM and DZX are related to $\mathrm{V}_{\max }$ completely independently. Unchanged $\mathrm{K}_{\mathrm{m}}$ values of all groups exposed to diazoxide action pointed to the fact that diazoxide did not cause any alterations in afinity of the ATP-binding site of the enzyme to the substrate (Table 2). The observed changes in kinetic parameters are characteristic for a noncompetitive type of enzyme activation.

In the kinetic parameters determination, the priority was given to the measurement of actual $\mathrm{Mg}^{2+}$-ATPase activity, i.e. the enzyme activity of that part of mitochondria with membrane permeabilisation. Addition of DNP into the incubating medium was omited in order to avoid a possible nonspecific interaction with diazoxide. Since diazoxide is known to have a wide range of the effects depending on the used concentration (Murata et al. 200, Kowaltowski et al. 2001), we selected one of the lowest concentrations that were proved to induce the evident protective effect in determination of DNP-stimulated $\mathrm{Mg}^{2+}$-ATPase activity, i.e. $7 \mu \mathrm{mol} . \mathrm{l}^{-1}$ diazoxide (Fig. 2).

We assume that acute STZ-DM seems to be a strong stimulus able to induce cardioprotective mechanisms such as modulation of mitochondrial membrane fluidity and mitochondrial ATP synthase activity in comparison with the effect of diazoxide. A combination of both experimental factors, STZ-DM+DZX, bring about a moderate increase in the parameters mentioned above with a considerable contribution of STZ-DM. Based on our experimental results we propose a new view of cardioprotection induced by diazoxide that does not act through the mitochondrial $\mathrm{K}_{\mathrm{ATP}}$ opening only, but presumably also through a direct interaction of diazoxide with the molecule of mitochondrial ATP synthase. That explanation is in accordance with the opinion by Contessi et al. (2004) who consider the stabilisation of Mg-ADP binding in catalytic site of the $\beta$ subunit of mitochondrial ATP synthase as a prerequisite for the general diazoxide action.

In conclusion, the experimental findings of our study provide evidence for different mechanisms 
of cardioprotection induced by pharmacological preconditioning with diazoxide and those induced by acute diabetes mellitus in terms of mitochondrial membrane properties. While acute STZ-DM stimulates ATP synthase activity indirectly, presumably via changes in the local lipid environment, the effect of diazoxide seems to be enabled by a direct interaction of diazoxide with the molecule of ATP synthase. These results point to a possibility of existence of a new, previously not recognized, mechanism of diazoxide's action on the induction of myocardial protection, which is independent of its effect on $\mathrm{K}_{\mathrm{ATP}}$ channels.

\section{Conflict of Interest}

There is no conflict of interest.

\section{Acknowledgements}

Supported by grants VEGA 2/0133/15, 2/0201/15; APVV-0102-11, APVV-15-0119.

\section{References}

BALYKIN MV, SAGIDOVA SA, ZHARKOV AV: Changes blood gas and of free radical oxidation of lipids in the myocardium during adaptation to physical stress. Ross Fiziol Zh Im I M Sechenova 101: 1007-1012, 2015.

BHADADA SV, GOYAL RK: Effect of aqueous extract of Tephrosia purpurea on cardiovascular complications and cataract associated with streptozotocin-induced diabetes in rats. Indian J Pharm Sci 77: 522-529, 2015.

CONTESSI S, METELLI G, MAVELLI I, LIPPE G: Diazoxide affects the IF1 inhibitor protein binding to F1 sector of beef heart F0F1ATPsynthase. Biochem Pharmacol 67: 1843-1851, 2004.

CRESTANELLO JA, DOLIBA NM, BABSKY AM, DOLIBA NM, NIIBORI K, OSBAKKEN MD, WHITMAN GJ: Mitochondrial function during ischemic preconditioning. Surgery 131: 172-178, 2002.

DZEJA PP, BAST P, OZCAN C, VALVERDE A, HOLMUHAMEDOV EL, VAN WYLEN DG: Targeting nucleotiderequiring enzymes: implications for diazoxide-induced cardioprotection. Am J Physiol Heart Circ Physiol 284: H1048-H1056, 2003.

EBRAHIMI H, BADALZADEH R, MOHAMMADI M, YOUSEFI B: Diosgenin attenuates inflammatory response induced by myocardial reperfusion injury: role of mitochondrial ATP-sensitive potassium channels. $J$ Physiol Biochem 70: 425-432, 2014.

FERKO M, GVOZDJAKOVÁ A, KUCHARSKÁ J, MUJKOŠOVÁ J, WACZULÍKOVÁ I, STYK J, RAVINGEROVÁ T, ZIEGELHÖFFER-MIHALOVIČOVÁ B, ZIEGELHÖFFER A: Functional remodeling of heart mitochondria in acute diabetes: interrelationships between damage, endogenous protection and adaptation. Gen Physiol Biophys 25: 397-413, 2006.

FERKO M, HABODÁSZOVÁ D, WACZULÍKOVÁ I, MUJKOŠOVÁ J, KUCHARSKÁ J, ŠIKUROVÁ L, ZIEGELHÖFFER B, STYK J, ZIEGELHÖFFER A: Endogenous protective mechanisms in remodeling of rat heart mitochondrial membranes in the acute phase of streptozotocin-induced diabetes. Physiol Res 57: 67-73, 2008.

FERKO M, KANCIROVÁ I, JAŠOVÁ M, WACZULÍKOVÁ I, ČARNICKÁ S, KUCHARSKÁ J, ULIČNÁ O, VANČOVÁ O, MURÁRIKOVÁ M, RAVINGEROVÁ T, ZIEGELHÖFFER A: Participation of heart mitochondria in myocardial protection against ischemia/reperfusion injury: benefit effects of short-term adaptation processes. Physiol Res 64 (Suppl 5): S617-S625, 2015.

GALANO A, TAN DX, REITER RJ: Melatonin as a natural ally against oxidative stress: a physicochemical examination. J Pineal Res 51: 1-16, 2011.

GARLID KD, PAUCEK P, YAROV-YAROVOY V, MURRAY HN, DARBENZIO RB, D'ALONZO AJ: Cardioprotective effect of diazoxide and its interaction with mitochondrial ATP-sensitive $\mathrm{K}+$ channels. Possible mechanism of cardioprotection. Circ Res 81: 1072-1082, 1997.

GOTZSCHE O: Myocardial catecholamine uptake and catecholamine sensitivity in experimental diabetes. In: The Diabetic Heart. NAGANO M, DHALLA NS (eds), Raven Press, New York, 1991, pp 199-208.

HOLMUHAMEDOV E, JOVANOVIC S, DZEJA P, JOVANOVIC A, TERZIC A: Mitochondrial ATP-sensitive K1 channels modulate cardiac mitochondrial function. Am J Physiol 275: H1567-H1576, 1998. 
KOBARA M, TATSUMI T, MATOBA S, YAMAHARA Y, NAKAGAWA C, OHTA B, MATSUMOTO T, INOUE D, ASAYAMA J, NAKAGAWA M: Effect of ischemic preconditioning on mitochondrial oxidative phosphorylation and high energy phosphates in rat hearts. J Mol Cell Cardiol 28: 417-428, 1996.

KOWALTOWSKI AJ, SEETHARAMAN S, PAUCEK P, GARLID KD: Bioenergetic consequences of opening the ATP-sensitive $\mathrm{K}(+)$ channel of heart mitochondria. Am J Physiol Heart Circ Physiol 280: H649-H657, 2001.

KRISTIAN T, BERNARDI P, SIESJÖ BK: Acidosis promotes the permeability transition in energized mitochondria: implications for reperfusion injury. J Neurotrauma 18: 1059-1074, 2001.

KÜBLER W, HAASS M: Cardioprotection: definition, classification, and fundamental principles. Heart 75: 330-333, 1996.

LENZEN S, PANTEN U: Characterization of succinate dehydrogenase and $\alpha$-glycerophosphate dehydrogenase in pancreatic islets. Biochem Med 30: 349-356, 1983.

LIU Y, THORNTON JD, COHEN MV, DOWNEY JM, SCHAFFER SW: Streptozotocin-induced non-insulindependent diabetes protects the heart from infarction. Circulation 88: 1273-1278, 1993.

LIU Y, SATO T, O'ROURKE B, MARBAN E: Mitochondrial ATP-dependent potassium channels: novel effectors of cardioprotection? Circulation 97: 2463-2469, 1998.

LOWRY OH, ROSEBROUGH NJ, FARR AL, RANDALL RJ: Protein measurement with the Folin phenol reagent. J Biol Chem 193: 265-275, 1951.

MALFITANO C, DE SOUZA JUNIOR AL, CARBONARO M, BOLSONI-LOPES A, FIGUEROA D, DE SOUZA LE, SILVA KA, CONSOLIM-COLOMBO F, CURI R, IRIGOYEN MC: Glucose and fatty acid metabolism in infarcted heart from streptozotocin-induced diabetic rats after 2 weeks of tissue remodeling. Cardiovasc Diabetol 14: 149, 2015.

MATEJÍKOVÁ J, RAVINGEROVÁ T, PANCZA D, ČARNICKÁ S, KOLÁŘ F: Mitochondrial KATP opening confers protection against lethal myocardial injury and ischaemia-induced arrhythmias in the rat heart via PI3K/Akt-dependent and -independent mechanisms. Can J Physiol Pharmacol 87: 1055-1062, 2009.

MUKUNDWA A, MUKARATIRWA S, MASOLA B: Effects of oleanolic acid on the insulin signaling pathway in skeletal muscle of streptozotocin-induced diabetic male Sprague-Dawley rats. J Diabetes 8: 98-108, 2016.

MURATA M, AKAO M, O'ROURKE B, MARBAN E: Mitochondrial ATP-sensitive potassium channels attenuate matrix $\mathrm{Ca}(2+)$ overload during simulated ischemia and reperfusion: possible mechanism of cardioprotection. Circ Res 89: 891-898, 2001.

MURRY CE, JENNINGS RB, REIMER KA: Preconditioning with ischemia: a delay of lethal cell injury in ischemic myocardium. Circulation 74: 1124-1136, 1986.

OZDEMIR O, AKALIN PP, BASPINAR N, HATIPOGLU F: Pathological changes in the acute phase of streptozotocin-induced diabetic rats. Bull Vet Inst Pulawy 53: 783-790, 2009.

PIERCE GN, DHALLA NS: Cardiac myofibrillar ATPase activity in diabetic rats. J Mol Cell Cardiol 13: 1063-1069, 1981.

PIOT C, CROISILLE P, STAAT P, THIBAULT H, RIOUFOL G, MEWTON N, ELBELGHITI R, CUNG TT, BONNEFOY E, ANGOULVANT D, MACIA C, RACZKA F, SPORTOUCH C, GAHIDE G, FINET G, ANDRÉ-FOUËT X, REVEL D, KIRKORIAN G, MONASSIER JP, DERUMEAUX G, OVIZE M: Effect of cyclosporine on reperfusion injury in acute myocardial infarction. $N$ Engl J Med 359: 473-481, 2008.

PORTENHAUSER R, SCHAFER G, TROLP R: Inhibition of mitochondrial metabolism by the diabetogenic thiadiazine diazoxide. II. Interaction with energy conservation and ion transport. Biochem Pharmacol 20: 2623-2632, 1971.

PRZYKLENK K, BAUER B, OVIZE M, KLONER RA, WHITTAKER P: Regional ischemic 'preconditioning' protects remote virgin myocardium from subsequent sustained coronary occlusion. Circulation 87: 893-899, 1993.

RAVINGEROVA T, STETKA R, VOLKOVOVA K, PANCZA D, DZURBA A, ZIEGELHÖFFER A: Acute diabetes modulates response to ischemia in isolated rat heart. Mol Cell Biochem 210: 143-151, 2000.

RAVINGEROVÁ T, NECKÁR̆ J, KOLÁ̌̆ F: Ischemic tolerance of rat hearts in acute and chronic phases of experimental diabetes. Mol Cell Biochem 249: 59-65, 2003.

RERUP CC: Drugs producing diabetes through damage of the insulin secreting cells. Pharmacol Rev 22: 485-518, 1970. 
SANADA S, KITAKAZE M, ASANUMA H, HARADA K, OGITA H, NODE K: Role of mitochondrial and sarcolemmal K(ATP) channels in ischemic preconditioning of the canine heart. Am J Physiol Heart Circ Physiol 280: H256-H263, 2001.

SHINITZKY M: Membrane fluidity and cellular functions. In: Physiology of Membrane Fluidity. M SHINITZKY (ed), CRC Press, Boca Raton, 1984, pp 1-51.

TANI M, NEELY JR: Hearts from diabetic rats are more resistant to in vitro ischemia: possible role of altered Ca2+ metabolism. Circ Res 62: 931-940, 1988.

TAUSSKY HH, SHORR E: A microcolorimetric method for determination of inorganic phosphorus. J Biol Chem 202: 675-685, 1953.

VOGEL WM, APSTEIN CS: Effects of alloxan-induced diabetes in ischemia-reperfusion injury in rabbit hearts. Circ Res 62: 975-982, 1988.

WACZULÍKOVÁ I, ZIEGELHÖFFER A, ORSZÁGHOVÁ Z, CÁRSKY J: Fluidising effect of resorcylidene aminoguanidine on sarcolemmal membranes in streptozotocin-diabetic rats: blunted adaptation of diabetic myocardium to Ca2+ overload. J Physiol Pharmacol 53: 727-739, 2002.

WACZULIKOVA I, HABODASZOVA D, CAGALINEC M, FERKO M, ULICNA O, MATEASIK A, SIKUROVA L, ZIEGELHÖFFER A: Mitochondrial membrane fluidity, potential, and calcium transients in the myocardium from acute diabetic rats. Can J Physiol Pharmacol 85: 372-381, 2007.

YTREHUS K, LIU Y, DOWNEY JM: Preconditioning protects ischemic rabbit heart by protein kinase C activation. Am J Physiol 266: H1145-H1152, 1994.

ZHAO ZQ, CORVERA JS, HALKOS ME, KERENDI F, WANG NP, GUYTON RA, VINTEN-JOHANSEN J: Inhibition of myocardial injury by ischemic postconditioning during reperfusion: comparison with ischemic preconditioning. Am J Physiol Heart Circ Physiol 285: H579-H588, 2003.

ZIEGELHÖFFER A, RAVINGEROVÁ T, STYK J, TRIBULOVÁ N, VOLKOVOVÁ K, ŠEBOKOVÁ J, BRIERER A: Diabetic cardiomyopathy in rats: biochemical mechanisms of increased tolerance to calcium overload. Diabetes Res Clin Pr 31: 93-103, 1996.

ZIEGELHÖFFER A, WACZULÍKOVÁ I, FERKO M, KINCELOVÁ D, ZIEGELHÖFFER B, RAVINGEROVÁ T, CAGALINEC M, SCHÖNBURG M, ZIEGELHOEFFER T, SIKUROVÁ L, ULICNÁ O, MUJKOSOVÁ J: Calcium signaling-mediated endogenous protection of cell energetics in the acutely diabetic myocardium. Can J Physiol Pharmacol 87: 1083-1094, 2009.

ZIEGELHÖFFER-MIHALOVIČOVÁ B, OKRUHLICOVÁ L, TRIBULOVÁ N, RAVINGEROVÁ T, VOLKOVOVÁ K, SEBOKOVÁ J, ZIEGELHÖFFER A: Mitochondrial contact sites detected by creatine phosphokinase activity in the hearts of normal and diabetic rats: is mitochondrial contact sites formation a calcium-dependent process? Gen Physiol Biophys 16: 329-338, 1997. 